\title{
無酸素性運動能力の評価 ーウインゲート無酸素性テストを中心に一
}

\author{
岩田 学*1 近藤 和 泉*2 細川賀乃子*2 \\ Evaluation of Anaerobic Performance \\ -A Description of the Wingate Anaerobic Test-
}

\author{
Manabu Iwata, ${ }^{* 1}$ Izumi Kondo, ${ }^{* 2}$ Kanoko HosoKawa ${ }^{* 2}$
}

\begin{abstract}
It has been generally considered that physical fitness is represented by exercise performance under aerobic conditions. However, we are often required to exert highly powerful movements momentarily or within a few seconds in daily life. Therefore, when we evaluate physical fitness, it appears important to evaluate physical fitness not only under aerobic conditions, but also under anaerobic conditions, with the latter being represented by maximal muscle power. In the daily living of people with physical disabilities, whether or not they can achieve a specific activity (for example, standing up, getting up from the floor and sitting down, etc.) is considered to depend on their performance under anaerobic conditions rather than under aerobic conditions. The Wingate anaerobic test (WAnT) has been developed as one of the most precise tests to evaluate anaerobic exercise performance. The WAnT, established at the Wingate Institute in Israel in 1970s, is a test incorporating bicycle riding with a maximal effort for 30 seconds. An ergometer with equipment to load an examinee with a constant resistance from a suspended weight is used in this test. The WAnT is measured as the changes in mechanical power that are yielded by multiplying the resistance produced from a suspended weight by the rotation speed of pedaling during a period of 30 seconds. The WAnT has not been usually applied so far to disabled people due to some technical problems. However, we have been improving the test to overcome those problems so that we can adopt the WAnT in the field of rehabilitation. We expect that this modified WAnT would contribute to a comprehensive evaluation of physical fitness in people with disabilities.
\end{abstract}

Key words : ウィンゲート無酸素性テスト (Wingate anaerobic test), 信頼性 (reliability), 妥当性 (validity), 筋力 (muscle strength), リハビリテーション (rehabilitation)

\section{はじめに}

体力関連の研究は, 従来健常者やスポーツアス

リートを対象として発展してきた経緯がある。最
近では高齢者や障害者を対象とした研究も多くみ られ，また介護予防の観点から，地域での体力増 進プログラムの導入が行われるようになってきて いる.しかしいずれにしてもそこで取り上げられ る体力は，有酸素性の運動能力が主体であり，体

2005 年 8 月 29 日受稿

*1 弘前大学医学部保健学科理学療法学専攻/ T 036-8564 青森県弘前市本町 66-1

Department of Physical Therapy, School of Health Sciences, Hirosaki University

*2 弘前大学医学部附属病院リハビリーション部/ T 036-8563 青森県弘前市本町 53

Rehabilitation Center, Hirosaki University Hospital 
力の構成要素の一つである無酸素性の運動能力に 関する関心は少ないように思われる。その理由と して，まず無酸素性の運動能力に対する理解が不 十分であることが挙げられる。無酸素性運動と は，運動中にまったく酸素を使わない運動ではな く，運動中のエネルギーが，主として解糖系など の酸素を必要としない経路によって供給される運 動といえる．最大筋パワーに代表される無酸素性 の運動能力は, 日常生活や運動競技において, 瞬 間的あるいは数秒間の高い強度のパワーを発揮す る場合の能力を意味し，そのような能力が求めら れる機会は生活上少なくはない。それにもかかわ らず，無酸素的な運動能力を評価することに対し て関心が薄いことの理由は, 適切で簡単に行える 検査が少ないことも影響していると考えられる.

そのような状況の中で, 無酸素性の運動能力を 的確に評価できるテストとして発展してきたの が，ウインゲート無酸素性テスト（Wingate anaerobic test, 以下 WAnT) である. WAnT は 1970 年代にイスラエルのウインゲート研究所 で開発された 30 秒間の最大努力下でのサイクリ ングテストである.このテストには重錘の懸垂に よって一定の抵抗力を負荷することができるエル ゴメータを使用する．WAnT は，懸垂された重 錘により生じる抵抗力とペダルの回転速度の積と して算出される機械的なパワーの 30 秒間の変化 をとらえたものである。現在までのところ，障害 者を対象としたWAnT の報告は非常に少ない が，今後いくつかの改変を重ねることでリハビリ テーション (以下，リ八）領域への応用が可能に なると考元られる。本稿では, リ八医療従事者 に, 無酸素性の運動能力についての理解を深めて もらうために，WAnTを主体に述べる.

\section{無酸素性運動能力の評価}

一般に無酸素性の運動能力の検査は, 非常に高 い強度で行われるが，運動時間としては 1 秒未満 のものから数分に及ぶものまである.多くの無酸 素性テストは，意欲がある人間を対象にする場合 は信頼性があり，各検査ともに非常に高い相関を
示すことは意見が一致している．それらの無酸素 性のテストは, 運動強度と運動時間がそれぞれ異 なっているが，極短時間（1～10 秒間）のテスト と短時間（20〜 60 秒間）のテストに分類するこ とが妥当と考えられる.

極短時間のテストとしては, 階段の走り上が $\eta^{1)}$, 跳躍 ${ }^{2}$, 最大速度での大きな筋群の収 縮 ${ }^{3,4)}$, 短距離走 ${ }^{5)}$, および自転車エルゴメー夕を 使用した大きな抵抗下でのペダル漕ぎ6,7)などが ある.WAnTにおける初期の 3 秒間ないしは 5 秒間の最大パワーも, この種のテストから得られ る情報と同一のものと考元られる。

一方短時間のテストでは，ほとんどの場合トレ ッドミルか自転車エルゴメータが使われる。これ らのテストでの測定值には, 特定の時間におけ る, 自転車エルゴメー夕上で出されたパワーの総 計8), 自転車上で与えられた抵抗に抗してペダル を踏み，完全に消耗してしまうまでの時間9), ま たは同じくトレッドミル上で与えられた速度と傾 斜で走って消耗してしまうまでの時間10 13) など が挙げられる.WAnTでは, 初期の 3 秒間ない しは 5 秒間の最大パワーの計測に加えて, 30 秒 間の上肢または下肢で出せる平均パワーを計測す ることが行われており，これは短時間のテストか ら得られる情報とみなすことができる.

ところで, ある課題が有酸素的なあるいは無酸 素的なエネルギー源の完全にどちらか一方のみを 使ってなされるとみなすのは間違いであり, WAnT を行うためのエネルギーの一部が有酸素 的な代謝経路から引き出されていることは当然考 えられる。しかしWAnTを「無酸素性テスト」 と見なすのであれば，無酸素的なエネルギー源の 関与が大きくなければならない. 数秒間以上のテ ストで, 有酸素性の要素と無酸素性の要素がそれ ぞれどの程度関与しているかを明らかにすること は困難であるが, Inbar ら ${ }^{14)}$ は, WAnT中の機 械的効率を 22 18\%と見なした場合, WAnTに おける有酸素性の要素の関与が $28 〜 13 \%$ になる と述べている.

また Kavanagh ら ${ }^{15)}$ は WAnTに対する有酸 素的な代謝の関連性を評価した報告を行ってい 
る.彼らの研究では, 被検者が室内の空気を吸っ た場合と，12\%の酸素を吸った場合（検査の 5 分 前から開始）の両方の条件で WAnTを行ってい る.その結果, 後者の状況では動脈血酸素飽和度 が，97.2\%から 88.6\%にまで低下した。しかし 低酸素の状態であるにもかかわらず最大パワーと 平均パワーの変化は有意ではなかったと報告して いる。この研究では WAnT に対する有酸素的な 要素の関与の程度を定量化することはできなかっ たが，低酸素状態が検査の成績に及ぼす影響がほ とんどないことが明らかにされた。

\section{ウインゲート無酸素性テストの方法}

WAnT がもっとも優れた無酸素性パワーの評 価テストかどうかを明らかにすることは難しい が，WAnT ほど最大筋パワーや筋持久力の評価 に用いられているテストは他にはなく，機械的最 大パワーおよび局所の筋の耐久性の情報を提供す るテストとしての高い信頼性と妥当性が多くの研 究で確認されている。

WAnT では一定の力に逆らって最大速度で 30 秒間にわたるペダル漕ぎあるいは腕でのクランク 回しが要求される。この力は最大上の機械的パワ 一を出させ，最初の数秒間で顕著な疲労（つまり パワーの急速な減少）を起こす．現在市販されて いるWAnT 用のエルゴメータ（図 1）には解析

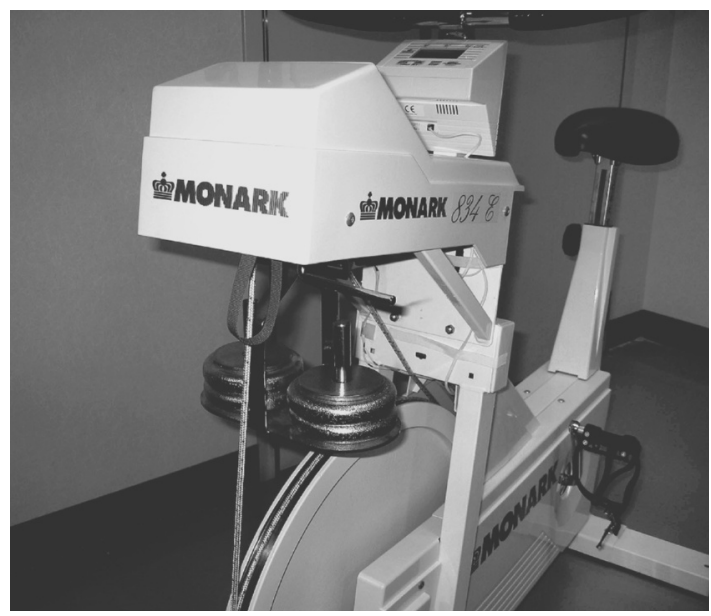

図 1 ウインゲートテスト用の機械式エルゴメータ
用のプログラムが付属されており，コンピュータ と連動して回転数が自動的に入力されるようにな っており，測定は非常に容易である。

実際の測定に際しては，テスト前にウォーミン グアップを要する。 5〜10 分間にわたる間欠的な 運動が，WAnTでより優れた結果を出すために 最も適していると報告されている ${ }^{16)}$.テスト開始 時にまず被検者は，重錘を負荷する前の，フライ ホイールの慣性と摩擦抵抗だけの状態でペダルを できるだけ速く踏み，可能な限り短い時間で最大 回転速度まで上げるように努力する。一旦重錘負 荷をかけてしまうと，それ以上速度を上げること はできないので，検者はペダルの回転速度が最大 速度に達したことを確認して，重錘を負荷する。 抵抗が加えられると同時に，ペダルの回転数の計 測が始まり，被検者は最大努力で 30 秒間それを 続ける。検者は，30 秒間のテストを通して，言 葉による励ましを与え続ける。特に最後の 10〜 15 秒間は非常につらく，最大努力を続けてもら うためにも，声かけは重要である。テスト終了後 被検者は，時としてめまいや悪心・嘔吐を起こす ことがある，それらを防ぐために，検査直後に軽 い抵抗下で $2 \sim 3$ 分間のクールダウンを行うこと が強く勧められる.

図 2 は，典型的な下肢の WAnT おけるパワー 曲線であり， 5 秒ごとの区間の平均值をプロット している.WAnTでは定常的な抵抗に対するぺ ダルの回転数を数えて，機械的なパワーを計測す る。それぞれの回転を完了するのに必要な時間が

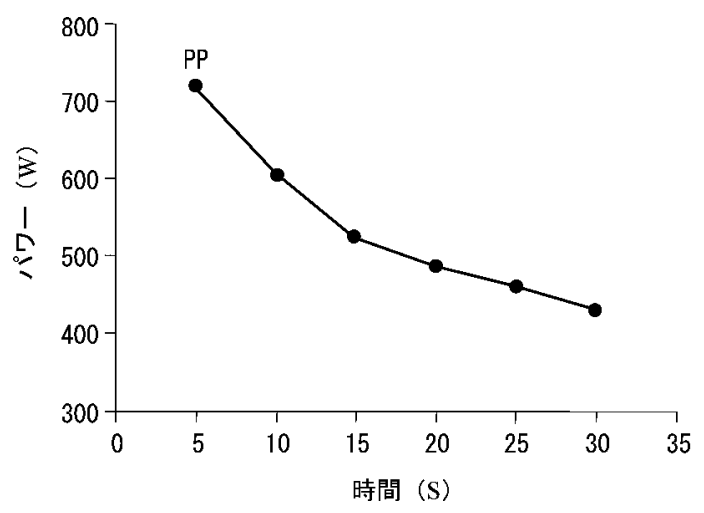

図 2 下肢の無酸素性パワーの典型的変化 
変動するので, WAnTでは 3 ないし 5 秒の区間 の平均を使っている.

WAnT では, 主に 2 つ運動能力の指標が計 測される.

1) 最大パワー (Peak Power, 以下 PP) は, テスト中に出たもっとも高い機械的パワーであ り，図 2 では点 PP として示されている.PPは 最初の数秒間に出されることが多いため，ほとん どの場合，この指標は最初の 3〜 秒の区間の平 均値を取るのが普通である。

2) 平均パワー (Mean Power, 以下 MP) は, 30 秒間を通じて保持されたパワーの平均である. この值は 10 個の 3 秒間の区間または 6 個の 5 秒 間の区間を平均して得られる。

WAnT では，それぞれの被検者でもっとも高 いPP と MP が引き出せる負荷量の設定を選ぶ ことが重要である，至適負荷量（Optima）は， 検査対象肢（上肢または下肢），性別，年齢，活 動レベル，使用するエルゴメータによって異な る ${ }^{17 \sim 19)}$ が，すべての被検者群の Optima は報告 されておらず，今後の継続的な研究が必要な部分 である。ちなみに，Monarkのエルゴメー夕を使 用して，男子学生が下肢の WAnT を行う場合の Optima は体重比で $87 \mathrm{~g} / \mathrm{kg}$ とされており ${ }^{18)}$, 体 重 $60 \mathrm{~kg}$ の学生の場合では, $5.22 \mathrm{~kg}$ の重錘を負 荷することになる。

WAnT の検查時間は従来より 30 秒とされてお り, 多くの研究デー夕の蓄積が 30 秒の WAnT を用いて行われている。しかし Vandewalle ら ${ }^{201}$ は，30〜40 秒間も続く検査に比べれば，短いテ ストの方が被検者の身体的負担が少なく容易に行 えるので, 無酸素的な検査は 15〜20 秒にすべき であると述べている。筆者らもテスト時間短縮の 妥当性の検討を, 32 名の健常人（男子 17 名：平 均年齢 23 歳, 女子 15 名：平均年齢 20.6 歳）で モナークエルゴメータを使用して検討してみた。

Optima を，男子で 0.087 ，女子で 0.085 とした 場合, WAnT の 15 秒までと 30 秒までの平均パ ワーの級内相関係数は, $0.99 \operatorname{ICC}(3,1)$, 体重 補正した場合でも $0.97 \operatorname{ICC}(3,1)$ と非常に高 い相関を得ている，今後この WAnTを高齢者や
障害者に応用する場合は, 安全性の問題から, テ ス卜時間の短縮が必要になると考えられるが，こ の結果は時間短縮版の WAnT が 30 秒の WAnT と類似の情報を提供する可能性を示唆していると 思われる。

WAnT の信頼性については, 一般的な環境下 での検查一再検査の相関係数が，0.89 から 0.99 であったと報告されている ${ }^{21,22)}$. 相関係数は, $\mathrm{PP}$ より $\mathrm{MP}$ で高くなる傾向があり，これは $\mathrm{PP}$ の測定の䛊差が大きいことを反映していると思わ れる。また検査の間に 30 分休みをはさめば，成 人で十分に信頼性のある結果が得られることが報 告されており ${ }^{21)}$ ，比較的短時間でテストを繰り返 し行えることはWAnT の大きな長所と言える。

一方 WAnT の妥当性については，比較すべき 最大パワーや上下肢の局所的な耐久性を測定する ためのスタンダードとなるテストが存在しないた め, 一般的な妥当性の検証を行うことは困難であ る.そこでいくつかの研究では, 無酸素性のパフ オーマンス能力と WAnT の結果を比較してい る。それによると, WAnT の結果が短距離走, 短距離の水泳, 短時間のアイススケートの課題, 垂直跳びの能力と相関することが報告されてい る22).これらの課題は, 高い強度の激しい動きを 要し, 数秒〜数十秒間継続されるので, かなり無 酸素的な課題と考えられる.WAnTで得られる MP P P と無酸素性の課題における運動遂行能 力との関連性は非常に高いが，それぞれの競技で 良い成績を出せるかどうかは，パワーだけではな く技術にも左右されるため, 特定の課題における 成績の予測にWAnTを使うことは難しいと考え られる。

\section{ウインゲート無酸素性テストと末梢筋力}

WAnTでは，いくつかの筋群が一体となった 上肢あるいは下肢の能力を測定しており，そのた め特定の筋や筋群に関する情報は本来提供できな い. しかし両者の関連性を検討した研究がいくつ か報告されている.

筆者ら ${ }^{23)}$ は，健常成人 32 名（平均年齢 21.9 
歳）で下肢の無酸素性パワーと下肢筋力との関連 性について調査した。 WAnTにはモナーク 430 Eエルゴメータを用い，PP と MP を算出した。 下肢筋力の測定には KIN-COM $500 \mathrm{H}$ を使用し, 膝屈曲 60 度における膝伸展筋の最大等尺性筋力 (Isometric Force：ISO) と角速度 120 度で連続 30 回の最大膝伸展屈曲運動における平均等運動 性筋力（Mean Torque：MT) を求めた。その 結果, 体重補正後の PP と ISO の間の相関係数 は $r=0.62 て ゙, \mathrm{MP}$ とT の間の相関係数は $r$ $=0.64$ で，いずれも有意であった（図 3).

また Stone ら ${ }^{24)}$ は, 20 名のサイクリストで $\mathrm{WAnT}$ の下肢の最大パワー $\left(\mathrm{W} \cdot \mathrm{kg}^{-1}\right)$ とパワ ートラックを用いた下肢の最大等尺性筋力（N・ $\left.\mathrm{kg}^{-1}\right)$ と間に $r=0.67$ の有意な相関を認めたと 報告している。

末梢筋力は無酸素性パワーに影響を及ぼす基本 的な要素であると考えられているが25 27), Takken ら ${ }^{28)}$ は，20 名の若年発症の特発性炎症性ミ オパチー患者で, WAnTに扔ける下肢の最大パ ワーと徒手筋力計による膝伸展筋力の関連性を検 討し，両者の間に有意な相関を認めたが，膝伸展 筋力だけでは，下肢の最大パワーの $24 \%$ しか説 明できないとし，他要因の関与を示唆している.

WAnTはいくつかの筋群が一体となった能力 を測定しており，そのため特定の筋や筋群に関す る情報は提供できない. 従って筋の収縮力や力一
速度曲線の作成といつた情報が必要であるなら ば，WAnTではなく，ダイナモメータ等による 単関節検査を行うべきである。

\section{ウインゲート無酸素性テストと環境温度}

WAnT は, 研究室ばかりでなく, 屋外の競技 場でも使えるように作られている。ただし Bergh ${ }^{29)}$ が, 深部体温が $1^{\circ} \mathrm{C}$ 低下するごとに無酸 素性の運動能力が $5 \%$ 低下することを報告してか らは，このテストを行うために気候・環境の条件 が標準化されているかどうかが検討されるように なっている。

環境温度の WAnT の結果への影響を検討した 幾つかの研究がある. Dotan ら $^{30)}$ は, 10〜 12 歳 の 28 人の小児が, 常温 $\left(22 \sim 23^{\circ} \mathrm{C}\right.$, 湿度 $55 \sim$ $60 \%)$, 高温乾燥 $\left(38 \sim 39^{\circ} \mathrm{C}\right.$, 湿度 $\left.25 \sim 30 \%\right)$, 温暖多湿 $\left(30^{\circ} \mathrm{C}\right.$, 湿度 85〜 90\%) の環境下でテ ストし, 各条件での運動能力を比較している。そ の結果 MP ではテスト-再テストの相関係数は 0.89 から 0.93 の範囲であった。またこれらの環 境間の PP および MP の差は有意ではなかった。 このため高温乾燥および温暖多湿気候下では, 小 児の運動能力は影響を受けないと報告している.

一方筆者らは，小児の無酸素性パワーに対する 低温暴露の影響について検討した ${ }^{31}$. 被検者は $10 \sim 12$ 歳の男児 12 名で, 低温暴露に人工気象室
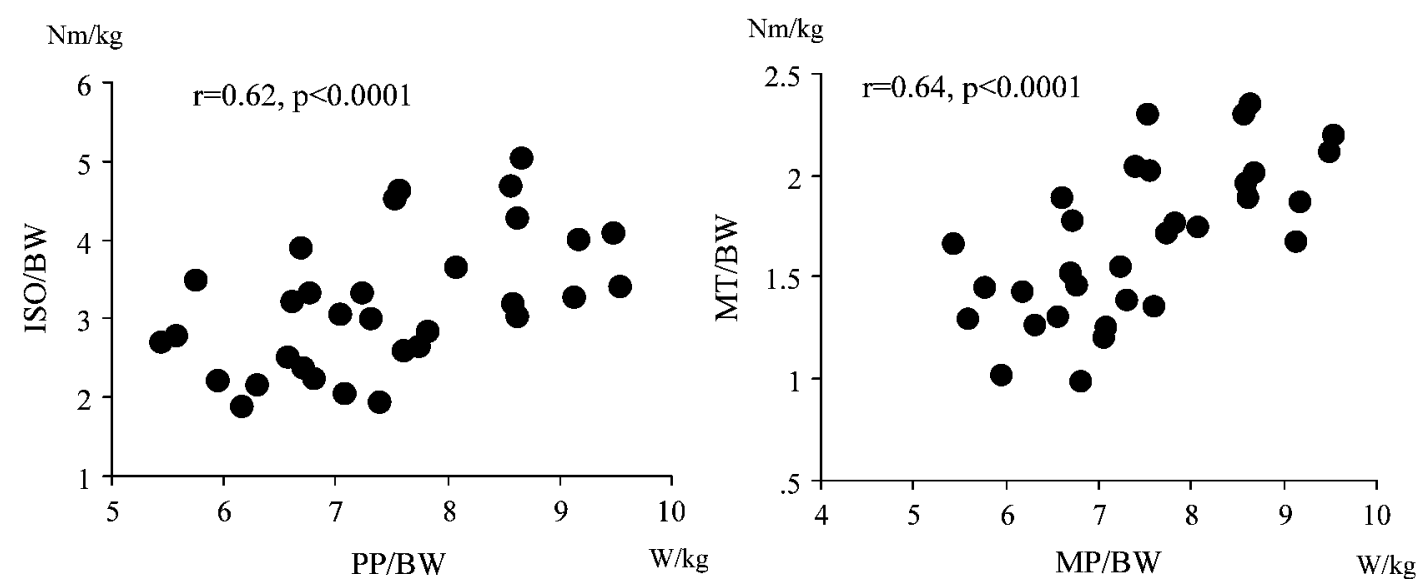

図 3 下肢の無酸素性パワーと膝伸展筋力との関係

PP : Peak Power, ISO : Isometric Force, MP : Mean Power, MT : Mean Torque, BW : Body Weight 

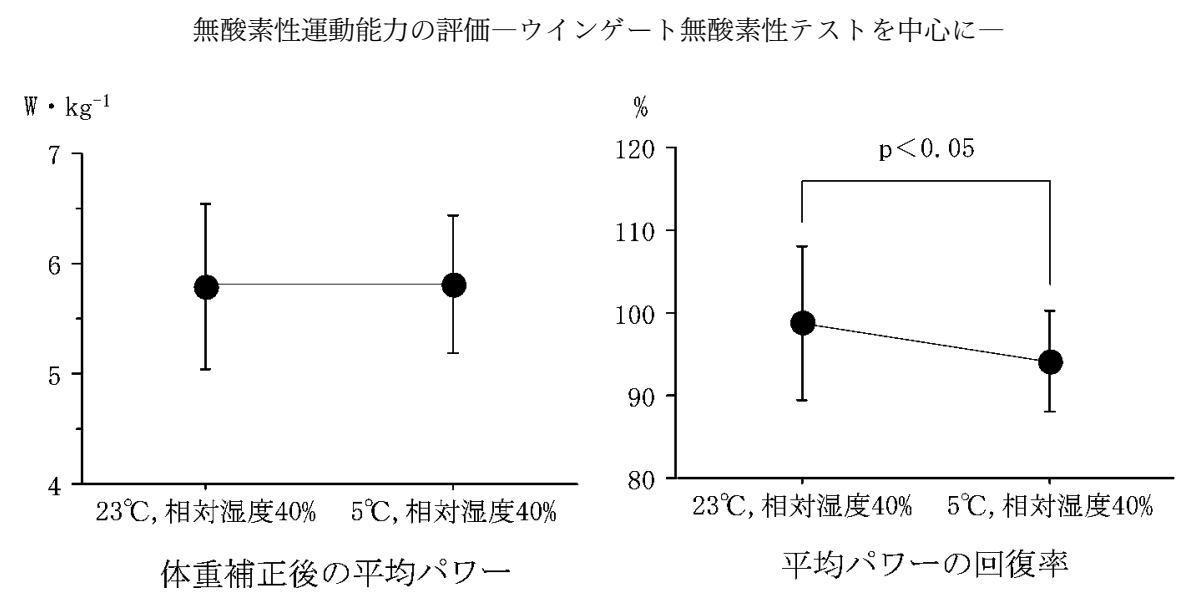

図 4 常温および低温環境における平均パワーおよびその回復率の比較 (文献 28 より用)

を使用し, 常温環境を $23^{\circ} \mathrm{C}$, 相対湿度 $40 \%$, 低 温環境を $5^{\circ} \mathrm{C}$ ，相対湿度 $40 \%$ に設定し，設定され たそれぞれの環境で 30 分間の安静の後, 1 回目 の WAnTを行い, 2 分間休鄎した後, 2 回目の WAnT を行った。その結果図 4 に示すように, 常温環境と低温環境で平均パワーの有意差が認め られなかったが, 平均パワーの回復率には有意差 が認められ，低温環境下では小児の運動能力の回 復が遅延することが示唆されている。

\section{ウインゲート無酸素性テストと神経筋疾患}

WAnT は従来健康人やスポーツアスリートに 使われて来たが，慢性の疾患や身体障害のある人 を評価するために使用されたこともある。ただし その際には, 身体運動能力の制限因子が呼吸循環 器ではなく神経・筋である場合に WAnT が適応 となる。

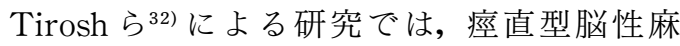
痺，アテトーゼ型脳性麻痺，Duchenne 型筋ジス トロフィー, Becker 型筋ジストロフィー，脊髄 性筋萎縮症, 先天性筋萎縮症と筋緊張性ジストロ フィーをもつ 6〜20 歳の 66 名の少年少女で，上 肢と下肢の WAnT が 2 度行われた。これらの被 検者のうち，上肢のテストと下肢のテストはそれ ぞれ $92 \%$ と $61 \%$ がうまく行われた。いずれのテ ストも行うことができなかった子供たちは，たい ていは Duchenne 型筋ジストロフィーであった。
一般に能力障害が進行していても, 下肢のテスト は松葉杖の有無にかかわらずまだ歩くことが可能 な子供たちでは行うことができる。この研究で は，信頼性の検討も行われているが，検査一再検 查信頼性係数は, 上肢の WAnT で PP が 0.94 , MPが 0.98, 下肢の WAnTでは PP, MP とも に0.96であったと述べている。またParker ら ${ }^{33)}$ は, $7 \sim 13$ 歳の 23 名の脳性麻痺児（片麻痺 5 名, 両麻痺 5 名, 四肢麻痺 13 名）を対象に WAnT を施行している. 23 名の脳性麻痺児は, 1 人を除いて移動に介助を要するか, 自立してい たとしても移動のための補助具（車椅子を含む） を必要とするレベルであったが，そのうち 22 名 が上肢 WAnT を，17 名が下肢 WAnT を完遂で きたと報告している.

一方 Fehlings ら ${ }^{34)}$ は，WAnTを用いて小児 ギラン・バレー患者の長期的な予後について調査 している．小児ギラン・バレー患者では，下肢の 筋パワーや筋持久力の回復が良好であるのに対し て，上肢では回復が遅延するため，上肢の筋持久 力を向上させるプログラムが必要であることが指 摘されている.

健康な人に使われている Optima は，筋量/体 量比が異常である能力障害のある患者には通常適 用できず，患者のための最適な抵抗力は知られて いない.これは筋萎縮あるいは顕著な肥満のある 人で特に顕著である。そのようなケースでは筋肉 量が体重から予測されるよりも小さいため, 通常 
の方法では最適な抵抗力を過大に設定しまうこと になる。

それに対してVan Mil ら ${ }^{35)}$ は, 最初に力一速 度テストで最適な力を識別して，次にその力の 65\%を使って WAnT を行うことによって，脳性 麻痺の若者に対する最適なブレーキング力を予測 できることを示唆している，もう 1 つの可能なア プローチとしては, 被検者の推定された除脂肪下 肢（または上肢）容量に対する最適な力の選択を 基にする方法が考えられる。しかしこの方法の適 応には妥当性の検証が必要である.

\section{おわりに}

WAnT が身体的な障害がある人で行われる場 合，WAnT の実行可能性と信頼性に関する問題 が残っている. 能力, フィットネスレベル, 活動 筋が異なるため，そのような人々のためにテスト を標準化する方法をさらに研究していく必要があ る.リ八領域で障害者の体力を包括的に評価して 行くためには, 有酸素性の運動能力だけではな く, 無酸素性の運動能力の評価も重要である。障 害者の日常生活においては, 特定の課題（例えば 立ち上がりや床から起き上がって座るなど）を達 成できるかどうかの成否は, 有酸素運動能力より はむしろ最大筋パワーに代表される無酸素性の運 動能力にかかっていると考えられる。その意味 で，本稿で紹介した WAnT は障害者の無酸素性 の運動能力を評価する上で，基本となるテストで あると考えられ，今後日本に抢いてもリ八領域へ の応用が期待される。

\section{文献}

1) Margaria R, Aghemo P, Rovelli E: Measurement of muscular power (anaerobic) in man. J Appl Physiol 1966; 21 : 1662-1664

2) Davies CTM: Human power output in exercise of short duration in relation to body size and composition. Ergonomics 1971; 14: 245-256

3) Komi PV, Rusko H, Vos J, Vihko V : Anaerobic performance capacity in athletes. Acta Physiol Scand 1977 ; 100 : 107-114

4) Thorstensson A, Hulten B, von Dobeln W, Karlsson $\mathrm{J}$ : Effect of strength training on enzyme activities and fibre characteristics in human skeletal muscle. Acta Physiol Scand 1976; 96 : 392-398

5) Fox E, Mathews D: Interval Training. Saunders, Boston, 1974

6) Crielaard JM, Pirnay F : Anaerobic and aerobic power of top athletes. Eur J Appl Physiol Occup Physiol 1981; 47: 295-300

7) Weltman A, Moffatt RJ, Stamford BA : Supramaximal training in females: effects on anaerobic power output, anaerobic capacity, and aerobic power. J Sports Med Phys Fitness 1978; 18 : 237244

8) Szogy A, Cherebetiu G: A 1-min bicycle ergometer test for determination of anaerobic capacity. Eur J Appl Physiol Occup Physiol 1974 ; 33 : 171-176

9) De Bruyn-Prevost P, Lefebvre F: The effects of various warming up intensities and durations during a short maximal anaerobic exercise. Eur J Appl Physiol Occup Physiol 1980 ; 43 : 101-107

10) Cunningham $D$, Faulkner $J$ : The effect of training on aerobic and anaerobic metabolism during a short exhaustive run. Med Sci Sports Exerc 1969; 1: $65-69$

11) Houston ME, Thomson JA: The response of endurance-adapted adults to intense anaerobic training. Eur J Appl Physiol Occup Physiol 1977; $36: 207-213$

12) Roberts $\mathrm{AD}$, Billeter $\mathrm{R}$, Howald $\mathrm{H}$ : Anaerobic muscle enzyme changes after interval training. Int J Sports Med 1982 ; 3: 18-21

13) Sjodin B, Thorstensson A, Frith K, Karlsson J : Effect of physical training on LDH activity and $\mathrm{LDH}$ isozyme pattern in human skeletal muscle. Acta Physiol Scand 1976; 97 : 150-157

14) Inbar $O$, Dotan $R$, Bar-Or O : Aerobic and anaerobic components of a thirty-second supuramaximal cycling task. Med Sci Sports Exerc 1976; 8: S 51

15) Kavanagh MJ, Jacobs IJ, Pope D, Hermiston A : The effect of hypoxia on performance of the Wingate anaerobic power test. Can J Appl Sports Sci $1986 ; 11: 22 \mathrm{P}$

16) Inbar O, Bar-Or $O$ : The effects of intermittent warm-up on 7-9 year-old boys. Eur J Appl Physiol Occup Physiol 1975; 34: 81-89

17) Evans JA, Quinney HA : Determination of resistance settings for anaerobic power testing. Can J Appl Sport Sci $1981 ; \mathbf{6}:$ 53-56

18) Dotan R, Bar-Or O: Load optimization for the Wingate Anaerobic Test. Eur J Appl Physiol Occup Physiol 1983; 51 : 409-417

19) Patton JF, Murphy MM, Frederick FA : Maximal power outputs during the Wingate anaerobic test. Int J Sports Med 1985; 6 : 82-85

20) Vandewalle H, Peres G, Monod H: Standard anaerobic exercise tests. Sports Med 1987 ; $4: 268^{-}$ 289

21) Hebestreit H, Mimura K, Bar-Or O : Recovery of 
muscle power after high-intensity short-term exercise : comparing boys and men. J Appl Physiol 1993; $74: 2875-2880$

22) Bar-Or O: The Wingate anaerobic test. An update on methodology, reliability and validity. Sports Med 1987 ; 4 : 381-394

23）岩田 学, 長谷川至, 近藤和泉, 佐藤能敬, 細川賀乃子, 相馬正始: 成人における無酸素性パワーと上下肢筋力 との関連性.リ八医学 $2002 ; 39$ (Suppl) : S 361

24) Stone MH, Sands WA, Carlock J, Callan S, Dickie D, Daigle K, Cotton J, Smith SL, Hartman M : The importance of isometric maximum strength and peak rate-of-force development in sprint cycling. J Strength Cond Res 2004 ; 18 : 878-884

25) Henry FM : Specificity vs generality in learning motor skills. Proc Coll Phys Educ Assoc 1958; 61 : 126-128

26) Henry FM, Lotter WS, Smith LE : Factorial structure of individual differences in limb speed, reaction and strength. Res Quart 1962 ; 33: 70-84

27) Macintosh D: The structure and nature of strength. J Sports Med Phys Fit 1974 ; 14 : 168-177

28) Takken T, van der Net J, Helders PJ : Anaerobic exercise capacity in patients with juvenile-onset idiopathic inflammatory myopathies. Arthritis
Rheum 2005; $53:$ 173-177

29) Bergh U : Human power at submaximal body temperature. Acta Physiol Scand 1980 ; (Suppl) : 478

30) Dotan R, Bar-Or O : Climatic heat stress and performance in the Wingate Anaerobic Test. Eur J Appl Physiol Occup Physiol 1980 ; 44 : 237-243

31）岩田 学, 近藤和泉, 細川賀乃子, 相馬正始, Henry RM，Bar-Or O : 小児の無酸素性パワーに対する低温 暴露の影響. リ八医学 $2001 ; 38: 981-985$

32) Tirosh E, Bar-Or O, Rosenbaum P: New muscle power test in neuromuscular disease. Feasibility and reliability. Am J Dis Child 1990 ; 144: 10831087

33) Parker DF, Carriere L, Hebestreit H, Bar-Or O : Anaerobic endurance and peak muscle power in children with spastic cerebral palsy. Am J Dis Child 1992 ; 146 : 1069-1073

34) Fehlings D, Vajsar J, Wilk B, Stephens D, Bar-Or $\mathrm{O}$ : Anaerobic muscle performance of children after long-term recovery from Guillain-Barre syndrome. Dev Med Child Neurol 2004 ; 46 : 689-693

35) Van Mil E, Schoeber N, Calvert RE, Bar-Or O : Optimization of force in the Wingate Test for children with a neuromuscular disease. Med Sci Sports Exerc 1996 ; 28 : 1087-1092 